\title{
Have France's éco-quartiers (eco-districts) made advances in resilient city-making? A discussion paper
}

\section{Est-ce que les écoquartiers suscitent des progrès pour la construction résiliente de la ville ? Un article de discussion}

\author{
Amy Oliver ${ }^{1}$, Emilie Gascon², Isabelle Thomas ${ }^{3}$ \\ ${ }^{1}$ École d'architecture, Faculté de l'aménagement, Université de Montréal \\ ${ }^{2}$ École nationale supérieure d'Architecture de Versailles, emilie.gascon@versailles.archi.fr \\ ${ }^{3}$ École d'urbanisme et d'architecture du paysage, Université de Montréal, isabelle.thomas.1@umontreal.ca
}

ABSTRACT. In order to deal with climate change and variability, many cities around the world have developed strategies to promote sustainable urban development (the "green agenda"), and in more recent years, urban resilience and adaptation (the "blue agenda"). In the past couple of decades, "eco-districts" have become an increasingly popular urban strategy for furthering the green agenda, the Écoquartier Program in France being one prominent example that aims at producing districts that are ecological, sustainable and innovative. But what about the blue agenda? This discussion paper explores to what extent France's Écoquartier Program helps to facilitate the integration of resilience, adaptation, disaster preparedness and risk reduction. It describes the evolution of the Écoquartier Program, the various requests for proposal, the Écoquartier Label, and design teams' responses to show the gradual incorporation and promotion of these concepts. It also uses an example of a certified and recognized écoquartier project in Paris, the Clichy-Batignolles écoquartier, to highlight the convergence of the green and blue agendas towards a "turquoise agenda". Finally, it discusses how the Écoquartier Program could help contribute to resilient city-making at the national scale.

KEYWORDS. Écoquartier Program, resilience, urban resilience, adaptation, turquoise agenda, Clichy-Batignolles.

\section{Overview of resilience, climate change and risks}

It is urgent to plan cities that integrate the understanding of uncertainties linked with climate change. Sustainable development is not a new concept, and many urban tools have been created so as to construct viable built environments. Still the climate crisis reinforces the need to include aspects of mitigation and adaptation in urban projects so as to build not only sustainable cities but also resilient communities. Is it crucial that researchers understand how specific projects can reinforce resilience in communities, as done in this paper.

Over the past few decades, discussions about climate change and variability (CCV) ${ }^{1}$ have led to two emerging agendas, the "green agenda" and the "blue agenda." Sustainable development has been around since the 1990s as a concept aiming at reducing the negative impacts of current ways of life on the natural systems and resources that support human life. While there are variations of this concept and its translation to urban planning (ecological, green, sustainable, regenerative design and development, etc.), the so-called "green agenda" has influenced hundreds of policies, programs, and certification systems aimed at sustainable buildings and urban development. More recent than the "green agenda," however, is the "blue agenda" - or those concepts relating to climate change adaptation and resilience. As the world has entered a new climate era, CCV poses great and

\footnotetext{
${ }^{1}$ Climate change is understood in this paper as "any change in climate over time, whether due to natural variability or as a result of human activity." (Griggs \& Noguer, 2002)
} 
globalized threats to cities. CCV affects cities in different ways, from short-term greater frequency and severity of extreme weather events and disasters to longer-term changes such as rising sea levels and temperatures. Many scientists and researchers believe that there is no escaping climate change; "Even societies with high adaptive capacity are vulnerable to climate change and variability and to climate extremes." (IPCC, 2007, p. 56) Defining urban actions, policies and plans for climate change - is thus urgent.

In order to promote the "green agenda," many cities have turned towards "eco-districts." The earliest examples of eco-districts can be found in Europe in the beginning of the 1960s (Joss, 2015). Whether in Denmark, Germany, Holland or Sweden, a result that these eco-districts above all highlight is the technical-environmental aspects of sustainable development. But what about the "blue agenda"? In this article, we use the example of France with its national ÉcoQuartiers Program and explore if and how écoquartiers are helpful in making advances in resilient city-making. This program, which can be translated in English to "eco-districts," was not necessarily originally intended to promote urban resilience. The program aims at producing districts that are ecological, sustainable and innovative, and it purports to be a platform for testing new technological responses, new design processes and new theories on ecological design. ${ }^{2}$ In this paper, we ask how "ecodistricts" can be relevant places to also test and promote the "blue agenda," or to in fact promote the "turquoise agenda," meaning both sustainable and resilient development. We ask, to what extent do France's écoquartiers consider future climatic conditions? To what extent does the Label ÉcoQuartier facilitate the incorporation of resilience, adaptation, disaster preparedness, and risk reduction?

This discussion paper presents a critical reflection on France's Écoquartiers and the extent to which they address the issues of urban resilient design, climate change adaptation, and disaster risk reduction. Though the paper does not present a scientific method with resilience criteria to analyse écoquartiers projects, it focuses on explaining the new paradigm in which the projects are implemented. It begins by briefly presenting a literature review on urban resilience and climate change adaptation. Next, by analyzing the Label ÉcoQuartier certification scheme as well as an example of a certified and recognized écoquartier project, it explores the application and integration of these concepts into the ÉcoQuartier Program. Finally, it puts this exploration into perspective and discusses how the ÉcoQuartier Program has evolved and can evolve further to better promote resilience and climate change adaptation.

\section{Brief literature review}

Although the concept of sustainable development (or the "green agenda") has been around for almost thirty years as a concept apt to address the challenges described above, the concepts of urban resilience, climate change adaptation, disaster preparedness, and risk management (the "blue agenda") are much more recent but are becoming unavoidable in the fields of architecture and urban planning. The cities of the future will arguably have to incorporate climate change adaptation strategies and urban resilience criteria in order to overcome environmental challenges. Cities should in fact be concerned with implementing a mix of the green and blue agendas, referred to by some scholars (Lizarralde et al., 2015; Oliver et al., 2013; Perelman, 2008) as the turquoise agenda.

The term "resilience" has evolved throughout recent decades and is characterized by several interpretations and used in many different fields. It may be defined broadly as the capacity to

\footnotetext{
2 Projects labelled as "éco-quartiers" are also important sites for innovation and experimentation - they are test labs. In this context of experimentation, an éco-quartier is not just a project to be implemented, "but becomes a tool for reflection on the transformation of urban development." (Saoumi, 2009, p. 17)
} 
prepare for, respond to, and recover from difficult situations (New York City, 2013); however, the concept of urban resilience is quite recent (Pelling, 2003). Just like the term resilience, the term adaptation also has taken on many different meanings. For example, some scholars and international organizations define adaptation in terms of "adjustment". This is the case of the Intergovernmental Panel on Climate Change (IPCC). Other definitions mention the term "process" (Burton, 1992; Smit et al., 2000; UKCIP, 2003; UNDP, 2005). Lastly, other definitions use the term "action." Resilience and adaptation are linked through the idea of risk. The concept of risk can be understood as being composed of three independent components (Crichton, 1999): hazard (i.e. potential damaging event); vulnerability (i.e. susceptibility to the hazard impacts); and exposure (i.e. being exposed to the hazard). In order to respond to these risks, mitigation measures that directly address the hazard and that aim at reducing the risk's driving forces, and adaptation measures that address the impacts of the hazard and work on exposure and vulnerability can and should be implemented (White, 2010, p. 110). To summarize, adaptation measures - understood by actions within an ongoing processcan be adopted in order to enhance a community's resilience.

\section{The Label ÉcoQuartier in France: a concept in evolution}

With over 500 local authorities participating in the ÉcoQuartier Club, the concept of 'écoquartier' has been defined iteratively and collectively since 2009 (About-de Chastenet et al., 2016). In the early 2000s, France was hit with an eco-district "fever" (Saoumi, 2009) wherein France's mayors and elected officials each wanted to develop his/her own eco-district. In 2007, the Grenelle de l'Environnement (a body that brings together French associations, companies and public bodies) conference recommended the construction of an eco-district in all municipalities that have significant housing development programs by the year 2012 (ibid). According to the Ministry of Ecology, Sustainable Development, Transport and Housing (MEDDTL for its acronym in French), the official definition of an écoquartier is: "a sustainable neighborhood encompassing considerations related to transport, density and urban forms, eco-construction, but also to social and functional diversity and civil society participation" ${ }^{3}$ (Ministère de l'Ecologie, 2011). Its design aims to "provide housing for all in a quality living environment, while limiting its ecological footprint" (ibid). Today, almost every urban community in France celebrates its own écoquartier, and as of 2016, there were 39 labelled ÉcoQuartiers in France as well as 98 commitments to working towards ÉcoQuartiers made by different municipalities. But once again, what is the link, if any, between the concept of écoquartiers and the concept of resilience?

A review of ÉcoQuartier documentation, including the different calls for proposals, media releases, and the ÉcoQuartier standard itself, as well as interviews with two researchers from Cerema $^{4}$ and a Parisian urban planner, reveals that the ÉcoQuartier concept is a concept very much in evolution. In the first call for proposals in 2009, French urban communities were invited to submit projects that promoted the aims of sustainable development (for instance energy efficiency, sustainable mobility, biodiversity), but the term "climate change" was not yet integrated into the project brief, not to mention the lack of "resilience," "adaptation," and "risk." The first 160 proposals drew interest from a diversity of project types: new neighbourhoods, rural neighbourhoods, urban wasteland revitalization and so forth. From here, the MEDDTL developed the first version of the Grille Label ÉcoQuartier, whose evolution is described below. A second call for proposals was then launched in 2011, this time inviting projects to consider climate change

\footnotetext{
${ }^{3}$ « Un quartier durable englobant des considérations liées aux transports, à la densité et aux formes urbaines, à l'écoconstruction, mais également à une mixité sociale et fonctionnelle et à la participation de la société civile » (Ministère de l'Ecologie, 2011).

${ }^{4}$ Center for Studies and Expertise on Risks, the Environment, Mobility and Development
} 
adaptation issues such as Urban Heat Islands (UHIs), thermal comfort in public spaces, and preventing risks of flooding. However, as a researcher from CEREMA explains, "In 2009 and 2011, risks were referred to, but not really in the forefront, more so in the choice of sites" (Researcher at le Cerema, 2019). And of the 394 projects submitted by local authorities in France, very few integrated the notions of "risk," "adaptation," and "resilience" (Richer, 2015). The researcher from Cerema explains that these entries also tended to focus more on GHG mitigation rather than climate change adaptation, a concept not yet very common in French communities (Researcher at le Cerema, 2019). After this call for proposals, the ÉcoQuartier Club was then formed to co-define the concept alongside local authority project teams and to develop a shared national database of projects (Aboutde Chastenet et al., 2016).

In the third call for proposals after 2013, there were 467 entries, each which expressed mitigation and adaptation options for each project site, especially with respect to energy, water, and green space in the city. Richer's analysis of these projects proposals (2015) shows four ways in which risk prevention issues were taken into consideration: major known risks outlined in public policies; risks that have evolved because of climate change; extreme heat waves; and rise in average temperatures. Competition entries focused on current knowledge of local risks, however, and did not consider future climatic conditions such as rises in average temperatures or rises in sea levels. To this fact, Richer therefore remarks: "While ÉcoQuartiers represent the best of contemporary development in France in terms of sustainable development, we can only note the very low consideration of future climate conditions and the obvious lack of adaptation provisions." (ibid) In this sense the competition entries in 2013 seemed to favour short-term to medium-term mitigation measures, rather than long-term adaptation strategies. That being said, in a summary document of the 13 winners published by the MDETL, only two of the projects explicitly mentioned risks and none made explicit mention of climate change, adaptation or resilience (Ministère de l'égalité des territoires et du logement, 2013). In the more recent call for proposals, a researcher from Cerema estimates that about one third of entries address risk, resilience and adaptation, and these entries mostly come from large cities and not from rural areas or smaller communities (Researcher at le Cerema, 2019). Comparatively speaking, a much larger number of entries take into account solar orientation, naturel ventilation, bioclimatic design, and other sustainable design principles. What continues to be missing, according to the researcher, are other subjects, such as drought, water resources, and extreme weather events (ibid).

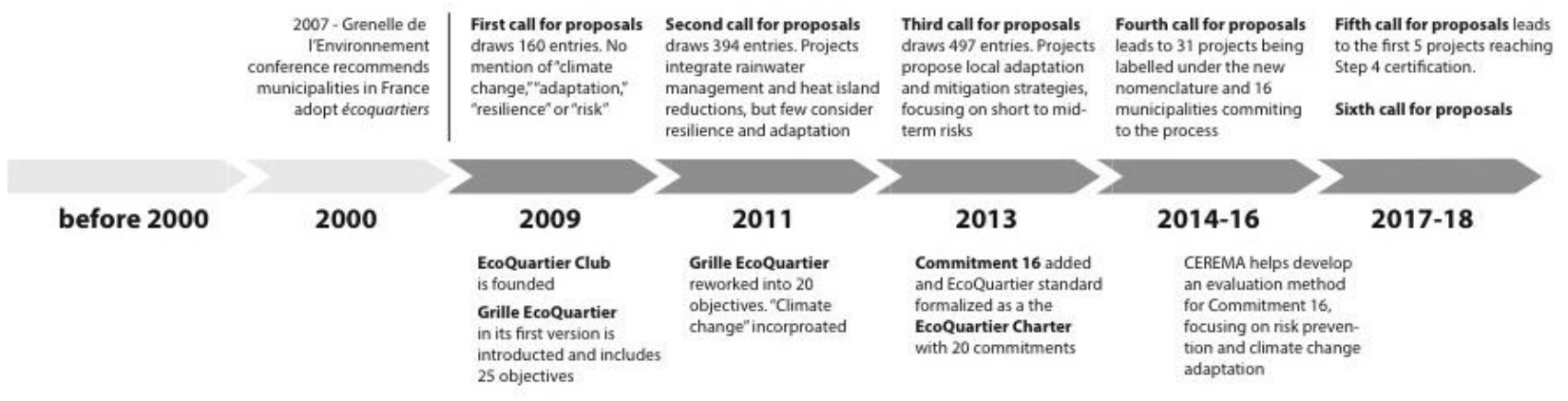

Figure 1. Evolution of the concept of ÉcoQuartier since 2009. Source: authors.

\footnotetext{
The ÉcoQuartier standard - a standard developed iteratively and in several different "generations".
}

\footnotetext{
5 « Si les ÉcoQuartiers représentent le meilleur de l'aménagement contemporain en France et en matière de développement durable, nous ne pouvons que constater la très faible prise en compte du climat futur et le manque patent de dispositions d'adaptation. » (Richer, 2015)
} 
In 2009, after the first call for proposals, the MEDDTL launched the first ÉcoQuartier standard (Grille ÉcoQuartier for its name in French), developed by a scientific committee alongside the government body AD4 and the National ÉcoQuartier Club. This standard synthesized national voluntary commitments and legislative regulatory commitments. It included 25 objectives organized under three different pillars, which were used by members of the competition jury to help judge competition entries. The standard was then re-worked in 2011 and supplemented by new indicators, such as participatory governance, strong political leadership, and reliable financial and legal arrangements (ibid., p. 11). In these first two versions of the ÉcoQuartier standard, however, the focus was mainly on the sustainable development (green agenda) side of climate change, and not the resilience (blue agenda) side of climate change. There was a clear lack of language and content relating to disaster risk reduction and building resilience, although indicator 16 did allude to "reduc[ing] greenhouse gas emissions and adapt[ing] to climate change." (Ministère de l'Ecologie, 2011 , p. 15) The standard was then again revised in 2013 to repackage the indicators as commitments in part of the ÉcoQuartier Charter, including commitment 16 in its current form. Please consult Table 1 at the end of this paper, which summarizes the 20 commitments as they stand in the 2015 version of the ÉcoQuartier standard.

Working with the Center for Studies and Expertise on Risks, the Environment, Mobility and Development (Cerema for its acronym in French), a public administrative body in France, the MEDDTL changed the wording of indicator 16 from the 2011 version from "Reduce greenhouse gas emissions and adapt to climate change" (MEDDTL, 2011, p. 15) to "Promote urban planning that anticipates and adapts to climate change and risks" (MEDDE, 2015, p. 19), thereby introducing the notion of risk (and anticipating risks) into the standard. In 2015, Cerema proposed a methodology for evaluating Commitment 16 in the form of a guide that is based on assessment of both current risks and anticipation of future climatic-sensitive risks (Bouyer et al., 2015). Based on the three major risks of flooding, reduced access to water, and heat waves, the guide proposes 15 indicators under four different headings. These different indicators are summarized below in Table 2 .

\begin{tabular}{ll}
\hline Overview & How many major risks are identified within the ÉcoQuartier perimeter (prescriptive \\
documents or knowledge base)? \\
- Area weighted by the level of hazards \\
- Number of inhabitants concerned and included in these hazard areas? \\
- Level of commitment of the project team upstream of the project on the resilience aspects \\
vis-à-vis risks and adaptation to CC (for example existence of scoping documents, specific \\
study, workshop) \\
- Level of overall commitment of the municipality vis-à-vis the risks, in particular crisis \\
management \\
- Will a significant increase or decrease in precipitation volumes due to climate change be \\
expected in the climate region of the ÉcoQuartier? \\
- Have these climatic evolutions been identified as aggravating the existing risks? \\
movement
\end{tabular}




\begin{tabular}{lll}
\hline Flooding & Flood envelope in which the ÉcoQuartier is located \\
& - Damage as a function of water level and duration of submersion \\
\hline Heat & Radiative balance: neighborhood albedo $(0<$ value $<1)$ \\
& Control buildings equipped with internal thermal room sensors for monitoring (and possible \\
& comparison with dynamic thermal simulations carried out during the design phase) (yes / \\
& no) \\
& High vegetation (trees, parks, etc.) $\left(\mathrm{m}^{2} \mathrm{veg} / \mathrm{m}^{2}\right.$ EcoQuartier surface)
\end{tabular}

Table 2. Evaluation criteria for engagement 16, proposed by Cerema. Source: adapted from Cerema, 2015.

Thus, it is important to understand this evolution in the conceptualization of what constitutes an écoquartier. While adaptation, risk reduction, and disaster resilience were not originally part of the ÉcoQuartier discourse, they have slowly been incorporated in the different generations of the ÉcoQuartier standard and different calls for proposals. And at the same time, the ÉcoQuartier standard has also evolved as a set of criteria used by judges to a formal charter of commitments for project teams to abide by. As a researcher from CEREMA explains, "We are a work in progress" (Researcher at le Cerema, 2019). Commitment 16 may continue to evolve and improve, perhaps by further stressing the importance of risk awareness. But incorporating disaster risk reduction and climate change adaptation language into ÉcoQuartier documents is one thing. Implementing these concepts in practice is another.

\section{What do built écoquartier examples teach us about resilience and climate change adaptation?}

The fact that the concept ÉcoQuartier is one in evolution is also evidenced by the built examples of écoquartiers. Many early examples of écoquartiers - that responded to the first two calls for proposals - were built in flood-prone areas and made no mention of disaster risk of reduction, climate change adaptation, or resilience in their competition entries or post-construction project documentation. Toubin et al. (2012) for example, comment on the "countless écoquartiers implanted in flood zones" and wonder about "their real contribution to the sustainability and resilience of these areas." But as the concept of ÉcoQuartier evolved along with the ÉcoQuartier standard, more projects started to consider risks, resilience, and climate adaptation in their proposals. Of the 32 écoquartiers that were certified in 2013 and 2014, one third of their profiles mentioned risks specific to their neighbourhoods; several mentioned wanting to go beyond minimum regulations; and half of them reported working on integrated storm water management so as to not aggravate downstream flood risk, thereby responding to the third qualitative description element in the Commitment 16 Evaluation document (Richer, 2015).

One recent example that prominently features the "blue agenda" alongside the "green agenda" is the Clichy-Batignolles écoquartier in the $17^{\text {th }}$ borough of Paris, scheduled to be completed in 2020. This écoquartier is located in a former railyard site (on the Petite Ceinture). It is 54 hectares in total and is set to be a mixed-use community featuring 3400 new housing units, space for the new courthouse and regional headquarters for the judicial police, $31000 \mathrm{~m} 2$ of retail and recreational space, and $38000 \mathrm{~m} 2$ of public facilities. The project boasts several innovative sustainable design strategies (green agenda): 
- A geothermal system that increases the neighbourhood's self-sufficiency in terms of heating needs, providing $83 \%$ of the district's heating needs ("Clichy-Batignolles: un quartier entier chauffé par la géothermie ", 2017) ;

- To move towards a neutral carbon footprint of the entire site, 40,000 m2 of photovoltaic roofs spread over the various buildings should produce around 4,500 MWh / year ("Clichy Batignolles," 2018), producing $40 \%$ of the electricity consumed in the buildings;

- All household waste (with the exception of glass and bulky items) is automatically collected using an underground pneumatic network, a first in Paris;

- And on the social sustainability front, the project includes 3400 dwellings of which $50 \%$ will be social housing, $30 \%$ owner housing and $20 \%$ capped-rent housing

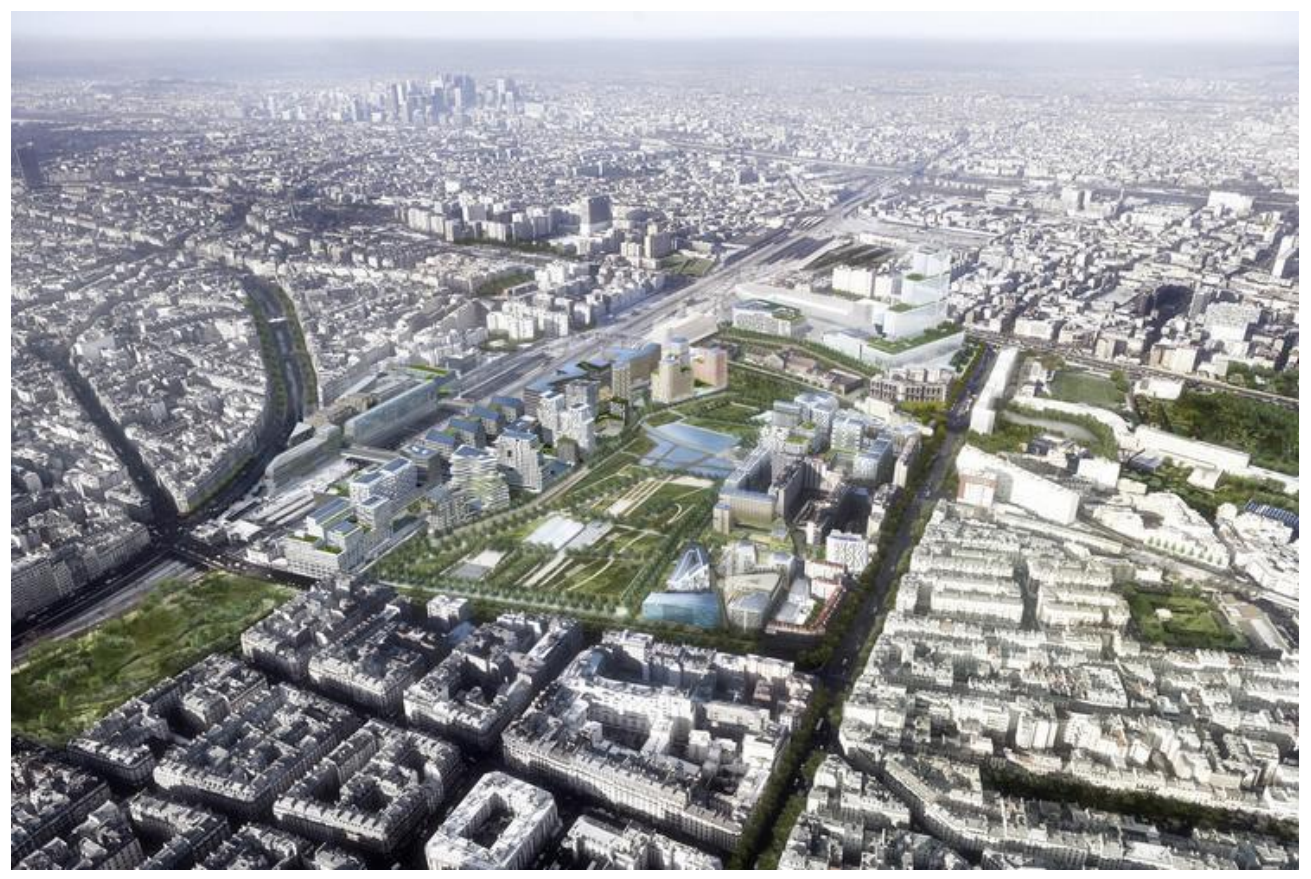

Figure 2. Aerial plan. Source: http://www.clichy-batignolles.fr/ (C) Vectuel-Studiosezz-PBA

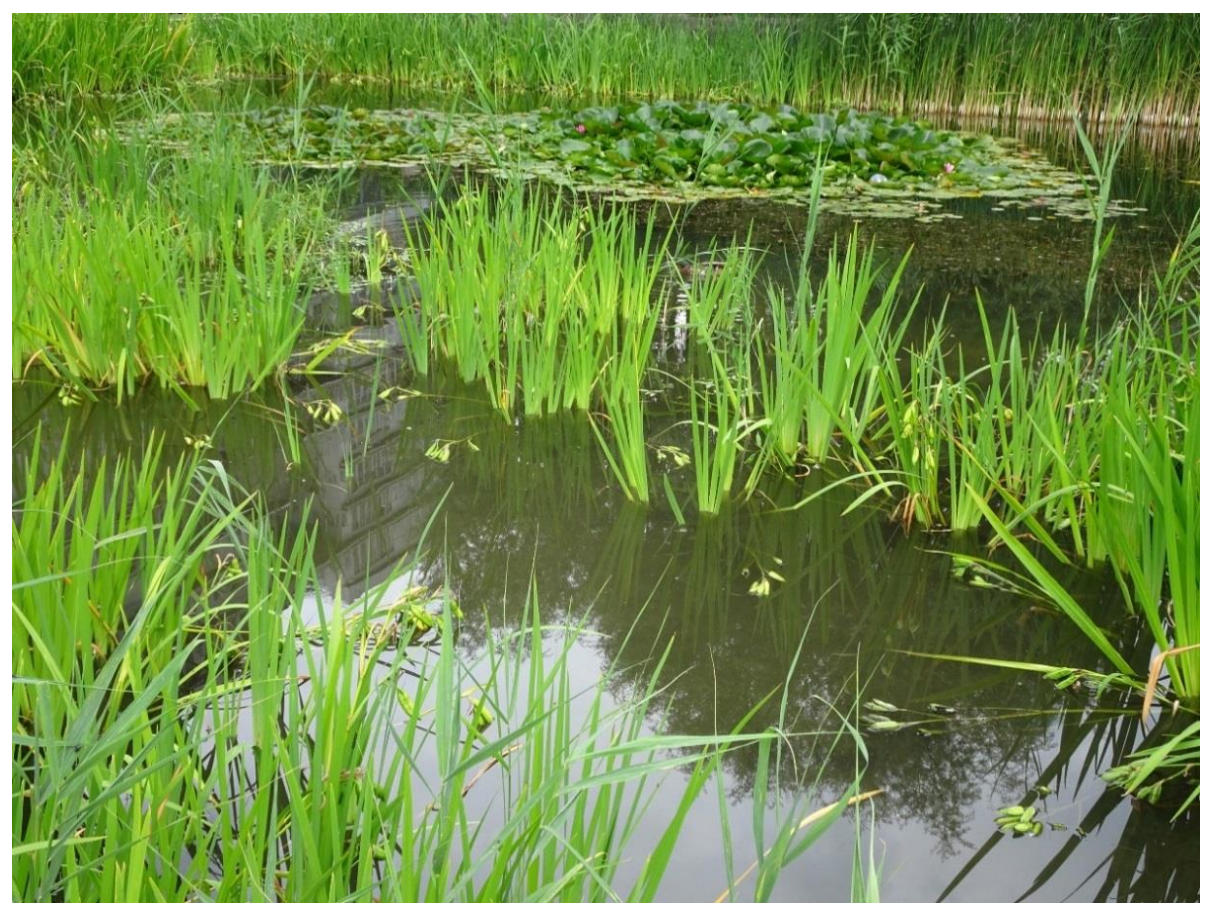

Figure 3. "Biotope" basin in Clichy-Batignolles écoquartier in Paris. Source: Gascon, 2018. 


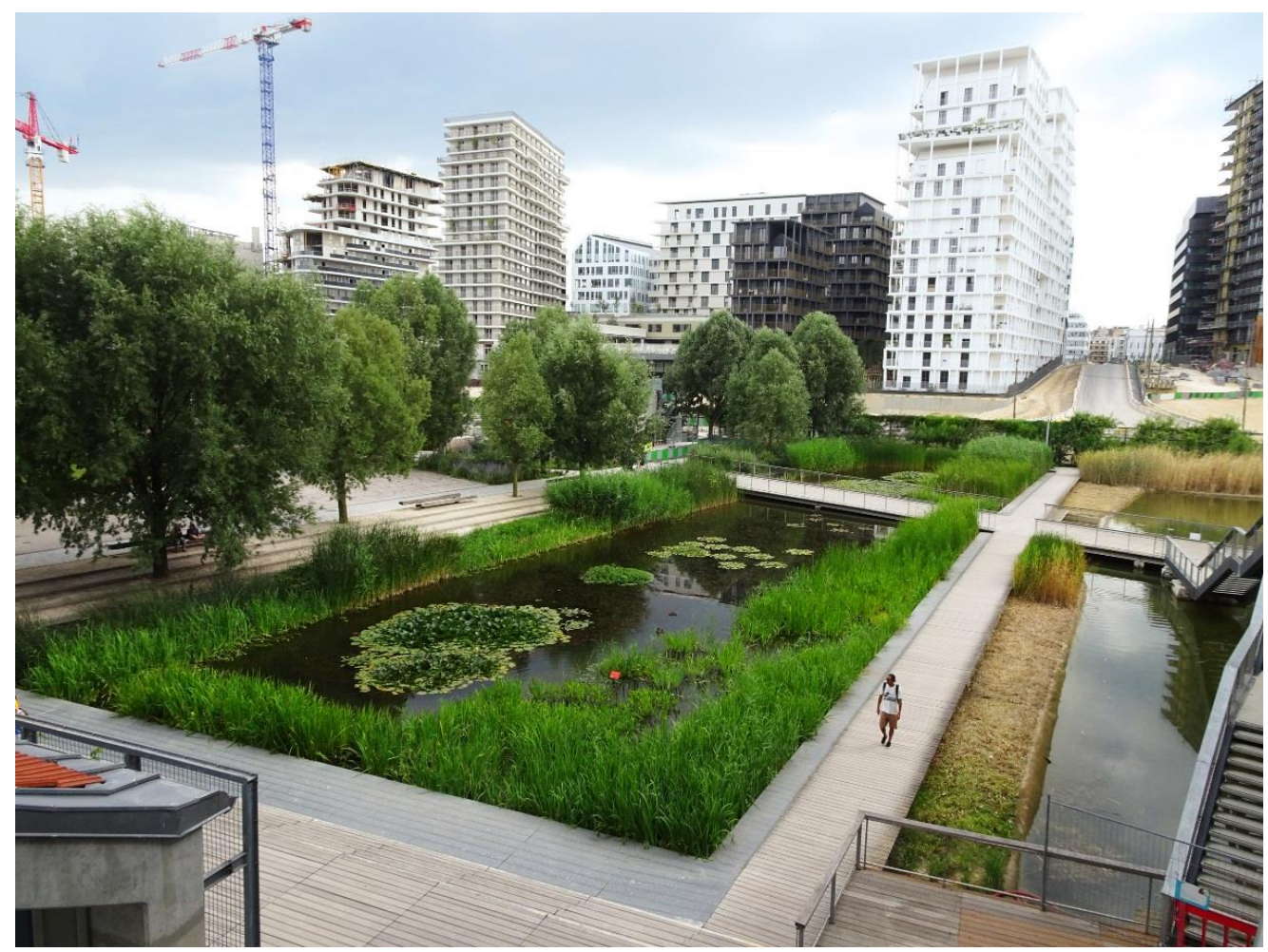

Figure 4. "Biotope" basin number 2 in Clichy-Batignolles, Paris. Source: Gascon, 2018.

The project was awarded a prize for environmental excellence by the Environment and Energy Management Agency (ADEME for its acronym in French) in the "Adaptation to climate change \& regional development" category in January 2017 as well as the Construction 21 Network Sustainable City Grand Prize in November, 2016. For the purposes of this paper, it is used as an example of best practices for promoting the turquoise agenda. The risks that the Clichy-Batignolles project needed to take into account for the Parisian context included extreme heat waves as well as intense rain and drought (the temperature in Paris is usually 2.5 degrees Celsius hotter than in surrounding rural areas, going up to 8.5 degrees warmer in extreme heat waves). The report published by ADEME called "Taking climate change into account in an urban development project: the ÉcoQuartier of Clichy-Batignolles," describes some of Paris' vulnerabilities that came to light in an in-depth diagnosis performed in 2011-2013. These included increased risks of flooding and saturation of the sewer network as well as the potential scarcity of water, energy and food resources. ${ }^{6}$ The city has made the ambitious choice to rely on the ecosystem services provided by the site to cool down urban spaces, cool down buildings, and optimize water management and to integrate the principle of sponge cities (Secchi \& Viganò, 2011). In doing so, it makes the neighbourhood more resilient to flooding.

To illustrate, the project includes a 10-hectare park that acts as a cooling island with water retention basins and natural ventilation strategies (proper orientation and spacing of buildings with a centralized park). Shade created by trees in the park as well as the natural phenomenon of evapotranspiration thus allow the park to function as an "air conditioner." It is estimated that the neighbourhood is around 2 degrees cooler than the rest of Paris at the end of the evening in conditions of extreme heat (ADEME). Strategies at the building scale include passive ventilation,

\footnotetext{
${ }^{6}$ It is worth noting that these physical risks identified by ADEME are quite different than the risks identified in Paris' Resilience Strategy for 100 Resilient Cities, which include: displaced populations / migrants, environmental degradation, extreme heat, homelessness, infrastructure failure, lack of affordable housing, rainfall flooding, and terrorism (100 Resilient Cities, 2018).
} 
natural daylighting, green roofs and green façades, and forbidding air conditioning machines, which reject heat into the air.

Water management strategies in the Clichy-Batignolles écoquartier project include the creation of constructed wetland ditches with a connected "biotope" basin that acts as a buffer to collect rainwater on site and that avoids flooding and pollution of the Seine River during intense rainfalls. It is also able to store water to meet the needs of the plants in the park. This collected and stored rainwater is transformed into water vapour that cools the ambient air. Rainwater is managed on a plot by plot basis, where each building or grouping of buildings on a plot collects rainwater and reuses it for its own needs, whether for watering plants or washing floors in the buildings. These water management strategies will thus allow for a 50\% reduction of rainwater discharged into the Parisian sewer networks from public spaces and a 70\% reduction on privately-owned land. The park and biotope basin, which finished construction in 2014, proved to be adequate buffers for the 2016 heavy rain episodes (ibid), highlighting the scheme's strength in reducing risks and enhancing resilience. Even if the écoquartier is not close to the River Seine, its benefits as a sponge help to minimize flooding at different scales. At the same time, the "biotope" basin increases biodiversity for the neighbourhood as it is home to water plants, ducks, moorhens, dragonflies and frogs, forming a rich ecosystem (ibid) and therefore serves the "green agenda" as well. All in all, the Clichy-Batignolles provides a solid example of how France's écoquartiers can be strategic areas for operationalizing the "turquoise agenda" - giving meaning to both sustainability and resilience.

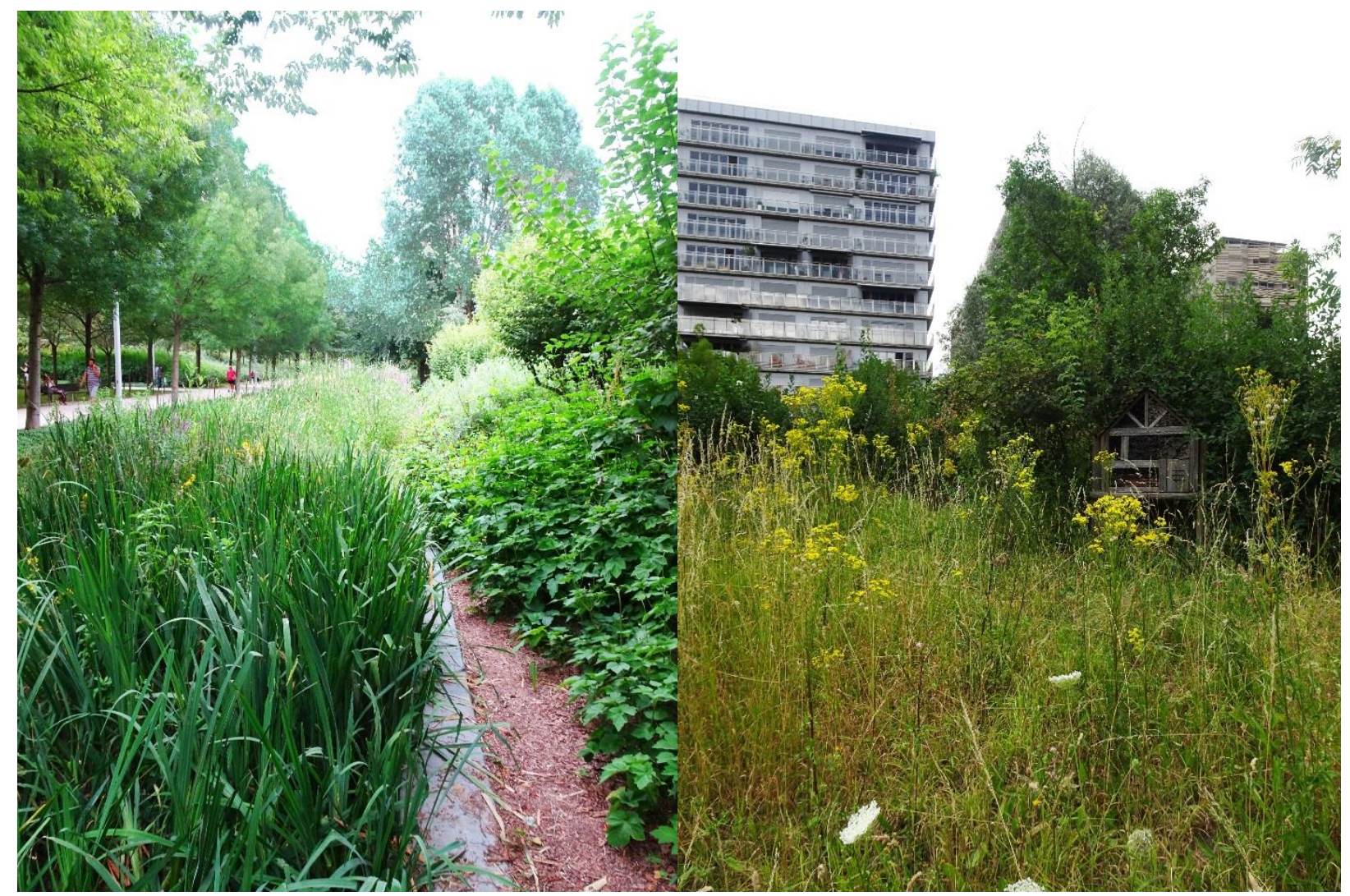

Figure 5. Shaded area and green corridor in Clichy-Batignolles' park in Paris. Source: Gascon, 2018. Figure 6. Wild vegetation and tree-house in Clichy-Batignolles écoquartier's biodiversity reserve in Paris. Source: Gascon, 2018.

\section{Does shifting the discourse lead to substantive change?}

It is interesting to note that the 2009 ÉcoQuartier competition entry for the Clichy-Batignolles project only tangentially mentions climate change adaptation (stating that it is one of the several 
goals of Paris' Climate Plan that the project will attempt to address). Nowhere in this 2009 competition entry are the words "resilience," "risk," or "flooding" mentioned. The competition entry does, however, present the 10-hectare park, which features a biotope pond with integrated rainwater management. But in this project competition document, the integrated water management / green infrastructure approach is presented more as a sustainable design strategy than a disaster resilience or climate change adaptation strategy.

The Clichy-Batignolles écoquartier design seems to not have changed much at all since the 2009 competition entry. The same baseline targets in the 2009 competition brief are presented in much later project documentation from 2015-2017: rainwater collection in the park is able to take care of $40 \%$ of the park's water-related needs; there will be a $50 \%$ reduction of rainwater discharged into the Parisian sanitation networks; heat production with at least $85 \%$ renewable energy (solar, biomass, geothermal), and so forth. Therefore, the main conceptual ideas behind the plan have not changed substantially (although more recent versions of the plan more prominently feature green walls and green roofs). The only thing that has changed is the way the project (and specifically water management, green infrastructure, and renewable energy strategies) has been conceptually packaged and marketed. What was in 2009 a holistic project about sustainable development is now communicated as a "cooling island," an "air conditioner," and a space that is designed to adapt to climate change and enhance resilience to heavy storms and rainfalls. Put differently, what was framed in the 2009 competition entry as responding to the "green agenda" is now framed as responding to the "turquoise agenda."

While cynics might argue that this shift in project marketing is evidence that resilience is nothing more than a buzzword with no real substance, in our view, this shift highlights the presence of the "turquoise agenda." Moreover, we argue that France's éécoquartiers are interesting areas for testing resilience and adaptation strategies, for educating citizens about risks (a key factor for enhancing a community's resilience), and for reducing vulnerabilities to disasters. They seem indeed to be relevant testing beds for contributing to the "turquoise agenda" and for creating more awareness in theory and in practice about how risk reduction, resilience and adaptation can be complementary and synergistic to sustainable design. The water management, green infrastructure and renewable energy strategies described above in the Clichy-Batignolles écoquartier are an example of this. In light of the heavy rain episodes in 2016, it can be seen as a model to follow, in the hopes that other ÉcoQuartier competition entries will soon follow suit or encourage innovation. This is made even more pertinent by the severe flooding in Paris in late 2017 and early 2018 and regularly life-costing flood events at the national scale.

\section{Discussion: the evolution of an ecosystemic resilience representation in France's ÉcoQuartiers}

This paper argued that if France's ÉcoQuartiers are to represent France's most virtuous efforts in operationalizing sustainable development, this sustainable development must also consider resilience to disasters and adaptation to climate change. It therefore seems important to critically reflect on the degree to which climate change and risk prevention considerations are adopted in the ÉcoQuartiers calls for proposals, Charter, and competition entries / built examples. The paper presented the conceptual and practical evolution of France's ÉcoQuartier Charter over the past ten years. While the first call for proposals in 2009 made no mention of climate change, risk, adaptation, or resilience, climate change gradually started to become more and more a part of the ÉcoQuartier agenda. In 2011, the ÉcoQuartier standard was reworked to include climate change issues such as reducing urban heat islands and dealing with rainwater runoff; however, in the second call for proposals in the same year, few projects took on risk, climate change adaptation and resilience in a serious way. It was not until 2013, when the ÉcoQuartier standard was repackaged into a Charter 
and Commitment 16 was reframed to incorporate an understanding of risk prevention and climate change adaptation, that more of a shift started to occur in the types of project proposals submitted in the ÉcoQuartier calls for proposals henceforth. With Cerema developing the evaluation methodology for assessing Commitment 16 of the ÉcoQuartier Charter, the ÉcoQuartier Program is starting to create a "culture of risk" or a "culture of resilience." While it is certainly too early to say that the ÉcoQuartier Charter has made this culture of adaptation deep-rooted in each and every one of the écoquartiers projects submitted, projects such as Clichy-Batignolles demonstrate that France's ÉcoQuartiers can make important advances in promoting the "turquoise agenda."

The question of operationalizing resilience and adaptation in eco-districts is a timely one given the signing of the Flood Resilient Neighbourhoods Charter ${ }^{7}$ (Direction Régionale et Interdépartementale de l'Environnement et de l'Énergie, 2018) in Paris on March $5^{\text {th }}, 2018$. This charter represents a purely voluntary commitment that encourages all actors to design neighbourhoods and cities to anticipate the risks of flooding. It is also designed to help actors in the early phases of project development understand issues related to evacuation or how to keep households safely at home in the event of a disaster (DRIEE Ile-de-France, 2018). This new charter is for the moment only a 5-page proposition, but it represents a first keystone in introducing the proper vocabulary and reflexes when building in flood-prone areas. It is even more timely given the millions of people participating worldwide in climate strikes on Fridays as part of an international movement of students who are protesting the lack of action taken to fight climate change and global warming.

When speaking of adaptation to climate change and resilience, it is important to consider the different spatial scales that require action. France's écoquartiers are at a scale - especially when taken in aggregate - that can have a real impact on France's ability to withstand future short-term and long-term disasters. However, at the same time, resilience and adaptation are questions that more often affect and can be grasped at the regional scale, rather than the smaller, neighbourhood scale. As such, it is important to understand how the ÉcoQuartiers Program can fit within city-scale and regional-scale policies and programs. For example, écoquartiers in Paris could fit within Paris' Resilience Strategy framework developed with 100 Resilient Cities $^{8}$ (Mairie de Paris, 2017). Some of the objectives and action points outlined in this Resilience Strategy target precisely the neighbourhood scale; for example, one objective is "creating the conditions for goodwill among neighbors and inclusion at the neighborhood level"; and another objective is to develop a circular economy and "living labs" at the neighbourhood scale (Mairie de Paris, 2017). There is also an opportunity to link the ÉcoQuartiers Program with existing public policies and resilience-building strategies in France: from the National Flood Risk Management Strategy (DGPR \& Ministère de l'Ecologie, 2014) to the Flood Risk Prevention Plans and the Flood Prevention Action Programs, the National Plan for Rapid Submersions (marine submersions, flash floods and breakwaters) or the implementation of the 2007 European Flood Directive ${ }^{9}$. Other programs at other scales are being

\footnotetext{
${ }^{7}$ Charte d'engagement pour « concevoir des quartiers résilients » face au risque d'inondation, Direction Régionale et Interdépartementale de l'Environnement et de l'Énergie (DRIEE), mars 2018. Available on http://www.driee.ile-de-france.developpementdurable.gouv.fr/IMG/pdf/2018 0312 charte quartiers resilients v5 sign-2.pdf (Accessed on the 03.05.2018)

8 For instance, the "prevention and resilience" working group in their "Recommendations for a new National Adaptation Plan for Climate Change' also recommends promoting écoquartiers as a model of climate resilience and promote their wide dissemination in the territories as well as any measure to introduce nature to the city.

${ }^{9}$ For their names and acronyms in French: La Stratégie Nationale de Gestion du Risque Inondation (SNGRI) (MEDDE, 2014) aux Plans de Prévention du Risque Inondation (PPRI) en passant par les Programmes d'actions de Prévention des Inondations (PAPI), le Plan national Submersions Rapides (PSR) (submersions marines, crues soudaines et ruptures de digues) ou encore la mise en œuvre de la Directive européenne Inondation (DI) de 2007.
} 
implemented in French cities to build resilience. For instance, in 2019, the Oasis schoolyards project, which aims at using school playgrounds so as to not only act as urban air coolers but also sponges, is considered widely a success. This project as well as the écoquartiers respond to the objectives of not only the "Adaptation to climate change strategy" but also the Paris's climate plan. They illustrate how cities can put ideas into action.

Another important point is that France's écoquartiers have a critical potential to build resilience if many of them are built and if they are linked to each other in a network and with other types of projects. In this way, they could be part of a regional or national experimental strategy rather than individual and disconnected projects. They can be used to test innovative adaptation strategies with multiple benefits: biodiversity, flood basins, sponges, air coolers, productive urban landscapes and generators of renewable electricity. When created with principles such as equity and affordability, they can enhance citizens' quality of life by fostering informal social networks. Still, cities have to create mechanisms such as new regulations and financial incentives, and simplify administrative procedures, so that these projects are not the exception, but the norm, leading to collective adaptation. These mechanisms and related resources need to be available not only to major cities, but also to smaller ones that do not have the same potential to adapt.

By jumping scales and coordinating efforts with other policies and programs like the ones mentioned above, écoquartiers can positively contribute to France' urban ecosystems. It is therefore time in the evolution of the ÉcoQuartier concept to move from creating a culture of awareness to a culture of action, with toolkits and resources for concretely enhancing resilience and climate change adaptation in France's écoquartiers. These processes and results could be replicated in other countries if adapted to local concepts as they enable to move from ideas to actions.

\begin{tabular}{|c|c|c|c|}
\hline $\begin{array}{l}\text { Approach and process: } \\
\text { developing projects differently }\end{array}$ & $\begin{array}{l}\text { Regional development: } \\
\text { galvanizing the territory }\end{array}$ & $\begin{array}{l}\text { Living environment and use: } \\
\text { improving daily life }\end{array}$ & $\begin{array}{l}\text { Resources preservation and } \\
\text { climate change adaptation: } \\
\text { responding to climate and } \\
\text { environmental emergency }\end{array}$ \\
\hline $\begin{array}{l}\text { 1) Realize projects that meet the } \\
\text { needs of all by relying on the } \\
\text { resources and constraints of the } \\
\text { territory }\end{array}$ & $\begin{array}{l}\text { 6) Work primarily on the existing } \\
\text { city and offer a density adapted } \\
\text { to fight against urban sprawl }\end{array}$ & $\begin{array}{l}\text { 11) Contribute to local, balanced } \\
\text { and united economic } \\
\text { development }\end{array}$ & $\begin{array}{l}\text { 16) Promote urban planning that } \\
\text { anticipates and adapts to climate } \\
\text { change and risks }\end{array}$ \\
\hline $\begin{array}{l}\text { 2) Formalize and implement a } \\
\text { steering process and broader } \\
\text { governance }\end{array}$ & $\begin{array}{l}\text { 7) Implement the conditions of } \\
\text { mixed (social and } \\
\text { intergenerational), good } \\
\text { community life and solidarity }\end{array}$ & $\begin{array}{l}\text { 12) Promote the diversity of } \\
\text { functions in the context of short- } \\
\text { distances } \\
\text { 13) Optimize the consumption of }\end{array}$ & $\begin{array}{l}\text { 17) Aim for energy conservation } \\
\text { and diversification of sources in } \\
\text { favor of renewable energy and } \\
\text { recovery }\end{array}$ \\
\hline $\begin{array}{l}\text { 3) Integrate the global cost } \\
\text { approach when making } \\
\text { investment choice }\end{array}$ & $\begin{array}{l}\text { 8) Offer a pleasant and healthy } \\
\text { lifestyle }\end{array}$ & $\begin{array}{l}\text { resources and materials and } \\
\text { develop local channels and short } \\
\text { circuits }\end{array}$ & $\begin{array}{l}\text { 18) Limit the production of waste } \\
\text { develop and consolidate recovery } \\
\text { and recycling channels }\end{array}$ \\
\hline $\begin{array}{l}\text { 4) Take into account the practical } \\
\text { constraints of users and } \\
\text { managers in design choices }\end{array}$ & $\begin{array}{l}\text { 9) Implement an architectural } \\
\text { and urban quality that balances } \\
\text { intensity and quality of life }\end{array}$ & $\begin{array}{l}\text { 14) Frame the project within the } \\
\text { concept of sustainable } \\
\text { development }\end{array}$ & $\begin{array}{l}\text { 19) Preserving water resources } \\
\text { and ensure a qualitative and } \\
\text { efficient management }\end{array}$ \\
\hline $\begin{array}{l}\text { 5) Implement continuous } \\
\text { evaluation and improvement } \\
\text { processes }\end{array}$ & $\begin{array}{l}\text { 10) Value local heritage (natural } \\
\text { and built), history and identity of } \\
\text { the neighborhood }\end{array}$ & $\begin{array}{l}\text { 15) Favor soft mobility and public } \\
\text { transit to reduce dependence on } \\
\text { cars }\end{array}$ & $\begin{array}{l}\text { 20) Preserve and enhance } \\
\text { biodiversity, soils and natural } \\
\text { environments }\end{array}$ \\
\hline
\end{tabular}

Table 1. The ÉcoQuartier standard (Grille ÉcoQuartier) and its 20 commitments. Evaluation method and National Reference Framework diagrams. Source: Translated from Ministère du Logement, 2015, p. 19. 
100 Resilient Cities. (2018). Paris' Resilience Challenge. Retrieved June 17th, 2018, from https://www.100resilientcities.org/cities/paris/

About-de Chastenet, C., Belziti, D., Bessis, B., Haucheux, F., Le Sceller, T., Monaco, F-X., \& Pech, P. (2016). The French eco-neighbourhood evaluation model: Contributions to sustainable city making and to the evolution of urban practices. Journal of environmental management, 176, 69-78.

ADEME. Prendre en compte le changement climatique dans un projet d'aménagement urbain : l'écoquartier de Clichy-Batignolles.

Bouyer, J. , Durin, B., Gastaud, P., Gerolin, A., \& Pouvesle, C. (2015). Méthodologie pour l'évaluation de l'engagement $16 \mathrm{du}$ Label ÉcoQuartier "Produire un urbanisme permettant d'anticiper et de s'adapter aux changements climatiques et aux risques » : rapport définitif. In Cerema (Ed.).

Burton, Ian. (1992). Adapt and thrive. Canadian Climate Centre unpublished manuscript, Downsview, Ontario.

Clichy Batignolles. (2018). Retrieved April 17th, 2018, from http://www.clichy-batignolles.fr/leco-quartier

Clichy-Batignolles: un quartier entier chauffé par la géothermie (2017). Retrieved le 17 avril, 2018 from https://www.paris.fr/actualites/clichy-batignolles-un-quartier-entier-chauffe-par-la-geothermie-4582

Crichton, David. (1999). The risk triangle. Natural disaster management, 102-103.

DGPR, \& Ministère de l'Ecologie, du Développement Durable et de l'Energie. (2014). Stratégie nationale de gestion des risques d'inondation (pp. 23).

Direction Régionale et Interdépartementale de l'Environnement et de l'Énergie. (2018). Charte d'engagement pour « concevoir des quartiers résilients » face au risque d'inondation. In S. P. d. R. e. d. Nuisances (Ed.). Paris, France.

Griggs, David J, \& Noguer, Maria. (2002). Climate change 2001: the scientific basis. Contribution of working group I to the third assessment report of the intergovernmental panel on climate change. Weather, 57(8), 267-269.

IPCC. (2007). Climate Change 2007: Impacts, Adaptation and Vulnerability. Contribution of Working Group II to the Fourth Assessment Report of the Intergovernmental Panel on Climate Change. In O. F. C. M.L. Parry, J.P. Palutikof, P.J. van der Linden and C.E. \& Hanson (Eds.), (pp. 976). Cambridge, UK.

Joss, Simon. (2015). Sustainable cities: Governing for urban innovation: Palgrave Macmillan.

Lizarralde, Gonzalo, Chmutina, Ksenia, Bosher, Lee, \& Dainty, Andrew. (2015). Sustainability and resilience in the built environment: The challenges of establishing a turquoise agenda in the UK. Sustainable Cities and Society, 15, 96-104.

Mairie de Paris. (2017). Stratégie de Résilience de Paris. Paris: 100 Resilient Cities.

Ministère de l'Ecologie, du Développement Durable, des Transports et du Logement,. (2011). La grille EcoQuartier 2011.

Ministère de l'égalité des territoires et du logement. (2013). Dossier de presse : Une démarche nationale qui engage l'urbanisme et l'aménagement dans la transition écologique. Partie 1: les 13 lauréats du label national. France.

New York City. (2013). PlaNYC: A Stronger, More Resilient New York. New York City: Office of the Mayor.

Oliver, Amy, Thomas, Isabelle, \& Thompson, Michelle M. (2013). Resilient and regenerative design in New Orleans: the case of the Make It Right project. SAPI EN. S. Surveys and Perspectives Integrating Environment and Society(6.1).

Pelling, Mark. (2003). The vulnerability of cities : natural disasters and social resilience. London ; Sterling, VA: Earthscan Publications.

Perelman, L. (2008). Infrastructure risk and renewal: The clash of blue and green. Paper presented at the Public entity risk institute symposium. Recommendations pour un nouveau Plan national d'adaptation au changement climatique.

Researcher at le Cerema. (2019). Informational interview. In A. Oliver (Ed.). Skype interview.

Richer, J. . (2015). ÉcoQuartier, l'adaptation en question. Paper presented at the "Changements climatiques, Aménagement de l'espace \& Transition urbanistique", Brest. 
Saoumi, T. . (2009). Éco-quartier, secrets de fabrication. Paris: Éditions Les carnets de l'info.

Secchi, Bernardo, \& Viganò, Paola. (2011). La ville poreuse: un projet pour le Grand Paris et la métropole de l'aprèsKyoto: MétisPresses.

SEMAVIP, Mairie de Paris \&. (2009). EcoQuartier Clichy Battignoles : Dossier de réponse Concours EcoQuartier.

Smit, Barry, Burton, Ian, Klein, Richard JT, \& Wandel, Johanna. (2000). An anatomy of adaptation to climate change and variability Societal Adaptation to Climate Variability and Change (pp. 223-251): Springer.

Toubin, Marie, Lhomme, Serge, Diab, Youssef, Serre, Damien, \& Laganier, Richard. (2012). La Résilience urbaine: un nouveau concept opérationnel vecteur de durabilité urbaine? Développement durable et territoires. Économie, géographie, politique, droit, sociologie, 3(1), 2-15.

UKCIP. (2003). Climate Change and Local Communities: How Prepared Are You? An Adaptation Guide for Local Authorities in the UK. Oxford.

UNDP. (2005). Adaptation Policy Frameworks for Climate Change: Developing Strategies, Policies and Measures. Cambridge: Cambridge University Press. 